\title{
FRONTOPARIETAL CORTICAL ATROPHY WITH GLIOSIS IN THE GRAY MATTER OF CEREBRAL CORTEX
}

\section{Case report}

\author{
Paulo Roberto de Brito-Marques', Roberto Vieira de Mello ${ }^{1,2}$, Luciano Montenegro ${ }^{1,2}$
}

\begin{abstract}
The case of a patient who suffered from progressive amnesia, depressive humor, language and visuospatial disturbances, and hallucination episodies with interference at the daily living activities is reported. She had moderate neuropsichological diffuse deficits at the first examination, especially at the executive and visuo-constructive functions. Her cerebrospinal fluid test presented high total protein. Magnetic resonance image showed slight white matter increase in periventricular, semi-oval center bilateral and left external capsule regions, besides light frontal and parietal lobe atrophy, bilaterally. Brain single photon emission computerized tomography revealed both a bilateral moderate frontal and a severe parietal lobe hypoperfusion, especially on the left side. Macroscopic examination showed cortical atrophy, severe on the frontal, moderate on the parietal and mild on the posterior third temporal lobes, bilaterally. There was a slight atrophy on the neostriatum in the basal ganglia. The histopathological findings of the autopsy showed severe neuronal loss with intensive gemioscytic gliosis and variable degrees of status spongiosus in cortical layer. Hematoxylineosin and Bielschowsky staining did not show neuronal swelling (balooned cell), argyrophilic inclusion (Pick's bodies), neurofibrillary tangles nor senile plaques. Immunohistochemical staining for anti-ubiquitin, anti-tau, anti- $\beta$-amyloide, and anti-prion protein were tested negative.
\end{abstract}

KEY WORDS: presenile dementia, cortical gliosis, diffuse neuronal loss, spongiosis, inespecific cortical atrophy.

\begin{abstract}
Atrofia cortical frontoparietal com gliose na substância cinzenta do córtex cerebral: relato de caso
RESUMO - É descrito o caso de uma paciente que apresentava amnésia, humor deprimido, distúrbio de linguagem e visoespacial, e alucinação visual com evolução progressiva, interferindo nas atividades de vida diária. Na primeira avaliação neuropsicológica havia déficit difuso de intensidade moderada, especialmente nas funções executivas e viso-construtivas. $O$ exame de líquido céfalo-raqueano mostrou a taxa de proteína elevada. Ressonância magnética evidenciou leve hiperintensidade de sinal na região periventricular, centro semi-oval bilateral, e alta hiperintensidade de sinal na região da cápsula interna esquerda, além de leve atrofia bilateral nos lobos frontoparietais. Tomografia cerebral por emissão de fóton único revelou hipoperfusão de intensidade moderada nos lobos frontais e severa nos parietais, especialmente à esquerda. Os achados de necrópsia evidenciaram atrofia cortical, sendo severa nos lobos frontais, moderada nos parietais e leve no terço posterior dos temporais. Havia também leve atrofia no neostriado. Do ponto de vista histopatológico, existia na camada cortical severa perda neuronal com intensa gliose gemioscítica e grau variável de status spongiosus. As colorações por hematoxilina-eosina e Bielschowsky não revelaram células baloniformes (células de Pick) e corpúsculos argirofílicos (corpos de Pick), degeneração neurofibrilar ou placa senil. As reações imuno-histoquímicas foram negativas para anti-ubiquitina, anti-tau, anti- $\beta$ amilóide e proteína anti-prion.
\end{abstract}

PALAVRAS-CHAVE: demência pré-senil, gliose cortical, perda neuronal difusa, espongiose, atrofia cortical inespecífica.

There are several progressive degenerative diseases of the central nervous system which are loosely classified in the literature as "presenile dementia". These several variants or subgroups are usually clinically indistinguishable ${ }^{1}$, despite some neuropsy- chological differences of right and left frontotemporal dementia compared to Alzheimer's disease $(A D)^{2}$. The most common of these disorders is $A D^{3}$. However, there are several presenile frontotemporal dementia types, which are much less common than

\footnotetext{
${ }^{1}$ Behavioral Neurology Unit, Department of Neurology, Faculty of Medical Sciences, University of Pernambuco, Brazil; ${ }^{2}$ Department of Pathology, Health Sciences Center, Federal University of Pernambuco, Brazil.
}

Received 24 September 2001, received in final form 16 January 2002. Accepted 29 January 2002.

Dr. Paulo Roberto de Brito-Marques - Rua Santa Terezinha 58 - 53140-170 Olinda PE - Brasil. E-mail: pbrito@truenet.com.br 
$A D$, like amyotrofic lateral sclerosis $(A L S)^{4}$, classic Pick's disease (PD) ${ }^{5}$, Creutzfeld-Jakob disease and the Heidenhain variant ${ }^{1}$, prion disease resembling frontotemporal dementia and parkinsonism linked to chromosome $17^{6}$, presenile dementia with diffuse calcified neurofibrillary tangles ${ }^{7}$, dementia with ALS features and diffuse Pick body-like inclusions ${ }^{8}$, and non-specific familial presenile dementia ${ }^{9}$. Most of these diseases are characterized by an insidious but invariably progressive deterioration of mental and physical capacities, culminating on a purely vegetative existence in which all patients need must be cared for ${ }^{1}$. In 1974, Constantinidis et al. ${ }^{10}$ after studying 32 cases of lobar atrophy, classify PD into three variants. Type $A$, which is classic PD; type $B$, the atrophic and gliosed cortex contained neuronal swellings but no argyrophilic inclusions and a number of those within type $B$ that would probably be diagnosed as cases of corticobasal degeneration ${ }^{11}$; and type $C$. In type $C$ the cases have neither Pick's bodies nor bollooned neurons, only gliosis and neuronal loss. There are 12 cases: eight cases with temporal atrophy $\left(C_{1}\right)$ and a strong gliosis found in the white axis of atrophied convolutions, and the other four cases with frontal lobe atrophy $\left(\mathrm{C}_{2}\right)$ and gliosis with extension to the precentral gyrus. This process spreads to the cingular, orbital, insular and even temporal areas. The neostriatum, pallidum, thalamus and locus niger are also severely involved and the lateral ventricles are strongly dilated. The symptomatology of the temporal group includes: moria, bipolar humor, and fixation amnesia, in some cases aphasic signs and transient logorrhoea. The symptoms of the frontal group include: apragmatism and depressive humor, frontal type dysmnesia, boulimia, gluttony, palilalia, echolalia, stereotypic activities and in some cases mutism.

The histological hallmarks of PD are not present in all cases that show typical clinical and macroscopic pathological features of the disease. Then, a further question related to the definition of PD is whether the condition should be expanded still further so that cases with a similar clinical presentation, but lacking gross lobar atrophy as well as Pick cells and Pick bodies, should be included. The consensus on these cases is that they should not be classified as cases of Pick's disease but as cases of non-specific frontal lobe dementia ${ }^{12}$. On the other hand, the so-called Pick's complex, contains the clinical variants of PD including a substantive overlap between the clinical syndromes of frontal lobe dementia, frontotemporal dementia, primary progressive aphasia, cortico-basal degeneration picture, an ALS associated with severe cortical degeneration and subcortical gliosis of temporal lobes ${ }^{13}$.

In keeping with this study, we have found similarities with our case with $C_{2}$ type of PD, but some differences still exist ${ }^{10}$. The report of this case involving the frontal and parietal and posterior third of temporal lobes shows the clinical and morphological aspects of a rare case of inespecific cortical atrophy.

\section{METHOD}

A diagnosis of progressive cortical frontoparietal gliosis associated with presenile dementia was made in a female patient according to Neary et al. ${ }^{14}$. Neuropsychological assessment was made on the basis of Mini-Mental State Examination (MMSE) ${ }^{15}$, Clinical Dementia Rating (CDR) ${ }^{16}$. She was also submitted to cerebrospinal fluid (CSF), and neuroimaging studies as magnetic resonance (MR) and to brain single photon emission computed tomography (SPECT). The neurophatological examination was performed according to European Concerted Action on PD ${ }^{17}$. The brain was fixed in $10 \%$ formalin for 4 weeks and cut into coronal sections. We examined $6-\mu \mathrm{m}$-thick paraffin-embedded sections from the middle frontal, upper temporal, middle temporal, parietal lobes, hippocampus and parahippocampus gyri, amygdaloid and Meynert nuclei of the brain. They were routinely processed and stained with hematoxilineosin, Masson, Wölcke's myelin and Bielschowsky methods. Immunohystochemical reactions with antibodies against tau, ubiquitin, $\beta$-amyloid and prion proteins were carried out.

\section{CASE}

When she first came to our observation in October 1995, the patient was a 50-year-old single woman. She was a maid. She spent 5 years studying at school, but she had only learned a little bit (she did not know how to handle money very well, she did not read very much, she could only write her name and make simple operations). At the age of 35, from a quiet meticulous efficient maid, she insidiously began to suffer from very slight memory disturbances without impairing at the daily living activities. A frequent complaint made by her boss was that the patient was no longer herself, or was losing her self. Afterwards, at the age 41, apparent and progressively she showed difficulties to perform sequences of motor tasks and she also presented memory deficits. Her daily living activities had to be reminded and she hesitated about having performed recent tasks. Small day-to-day events were not remembered. A few used words from an earlier period of her life also tended to be lost. Appointments were forgotten and belongings misplaced. For about three years prior to presentation she had developed a progressive language disturbance. She was also unable to find her way around the neighbourhood and other formerly familiar environments. She presented some hallucination episodies at 
home. At the age of 50, moderate anterograde persistent amnesia appeared, she was not aware of her forgetfulness. Questions were repetead again and again, she forgot what had just been discussed. She tended to neglect the care of herself as well as that of the house, and her memory deficits had increased, involving also autobiographical memory. She confabulated about past events and tended to get lost in her rambling discourse. Her spontaneous speech disappeared with progressive reduction, stereotype of speech (repetition of limited repertoire of words, or small phrases). Under these conditions her solo excursions were sharply limited. The patient had no history of hypertension, diabetes and other vascular risk factors. Her family history disclosed no dementing diseases. No psychiatric abnormalities emerged from her medical history.

The findings of the neurological examination 10 years after the onset of symptoms revealed a right-handed woman. She was limited by poor schooling. The MMSE ${ }^{15}$, scoring $06 / 30$ and $C D R, 2^{16}$. She was fully desoriented in time and space, but she had collaborated adequately during the test sessions. The pattern of her memory impairment manifested itself as extreme difficulty in tasks with attentional requests. Memory in everyday life seemed very disturbed. The language in informal conversation was very poor in content, she resorted to ceremonial expressions and got lost in circumlocutions demonstrating very poor verbal planning abilities; she also presented many anomias in spontaneous speech. Comprehension seemed also very impaired. As a whole, verbal communication appeared very disturbed, even if there were no clear aphasic deficits. She named almost all common objects correctly. At this state, the simplest of geometric forms and patterns could not be copied. Her copy of a overlap pentagones was very altered.

Routine biochemical, haematological and sorological investigations were normal. The CSF from basal cistern test showed an increase in total protein content $(60 \mathrm{mg} /$ dl). It also included the research of virus, and electrophoretic methods. Her MRI performed when she was 50 years old revealed a slight white matter increase in the periventricular, semi-oval center bilateral and left external capsule regions. There were also a slight bilateral frontal and parietal lobes atrophy. Six months after initial evaluation, a SPECT using ${ }^{99 \mathrm{mTC}} \mathrm{T}-\mathrm{h}$ examethyl propyleneamine oxime ( $\left.{ }^{99 \mathrm{~m} T \mathrm{TC}} \mathrm{HMPAO}\right)$ showed moderate bilateral frontal and parietal lobes hypoperfusion, especially on the left side. Her cerebral blood flow ranged from 35 to $42 \mathrm{ml} / 100 \mathrm{~g}$ tissue/min (normal 65-85) in the visual and temporal cortex (Fig 1).

During the use of anticholinesterasic drug by 18 months her copy of overlap pentagones (Fig 2) and some daily living activities had improved. For about three years preceeding her death, she had started to develop a progressive verbal inertia, and an stereotyped expression appeared, reduced communication and comprehension to a minimum, almost as a global aphasia. Despite all that she still answered with automatic language. She evolved into a clinical picture of palilalia, echolalia and mutism. The patient forgot how to use common objects and tools while

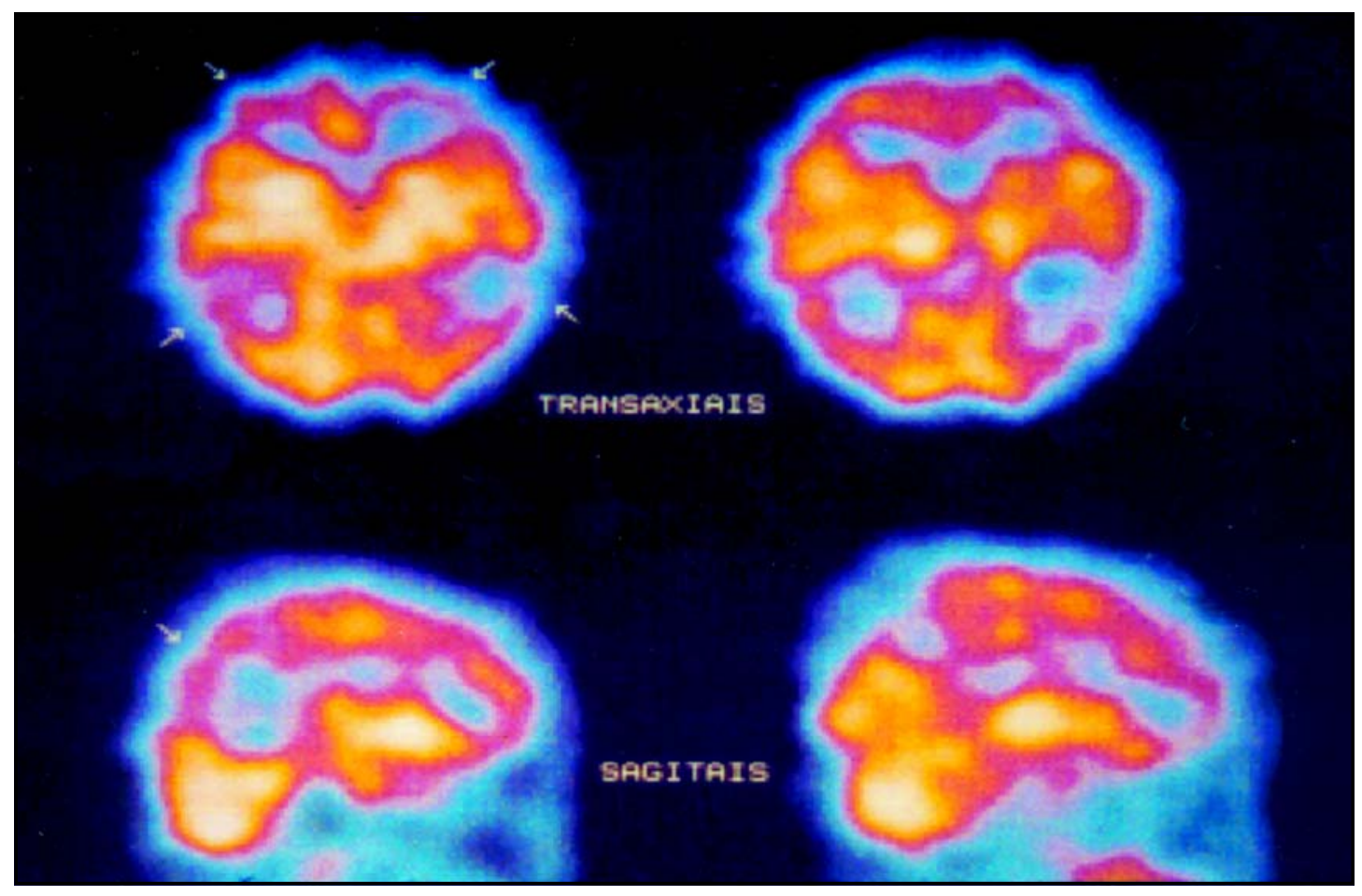

Fig1. SPECT using ${ }^{99 m}$ Tc-hexamethyl propyleneamine oxime ( ${ }^{99 m} T C$ HMPAO) showed moderate bilateral frontal and parietal lobe hypoperfusion, especially on the left side. 


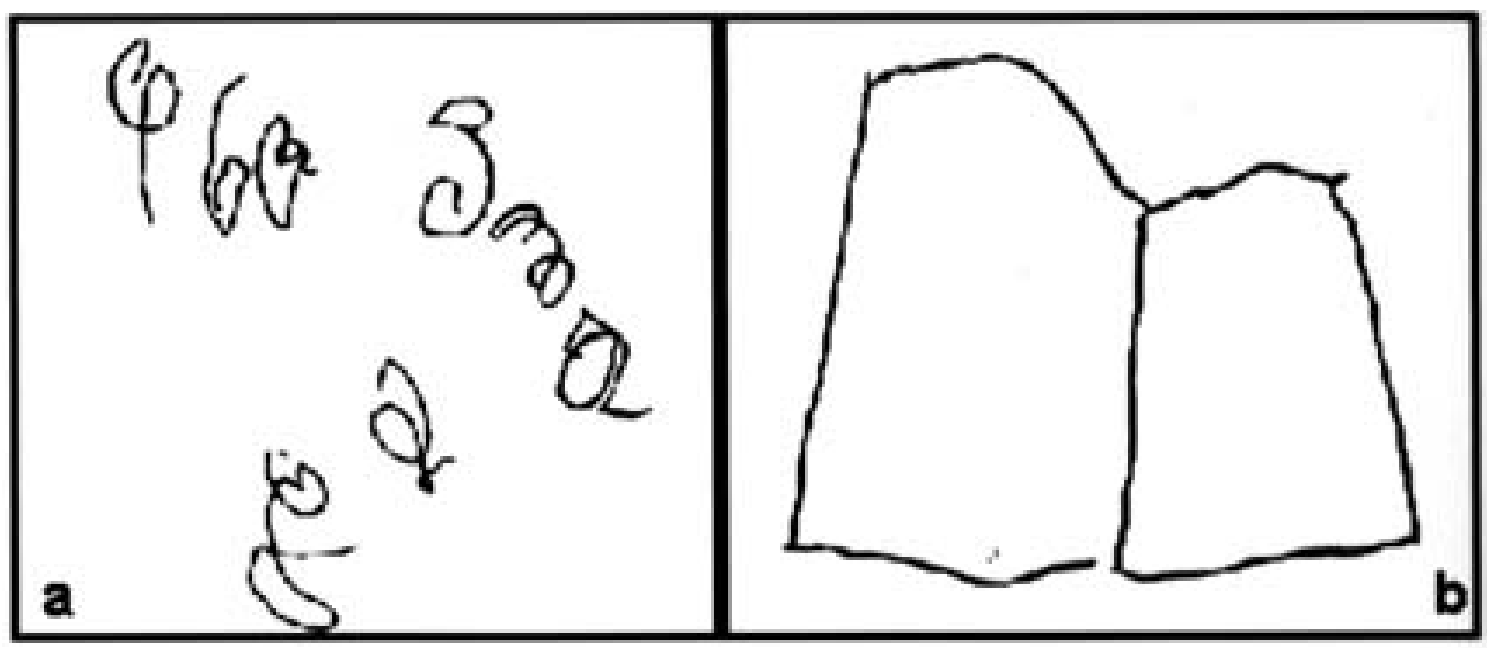

Fig 2 a,b. The overlap pentagones copy was very disturbed. The overlap pentagones copy was less disturbed during treatment.

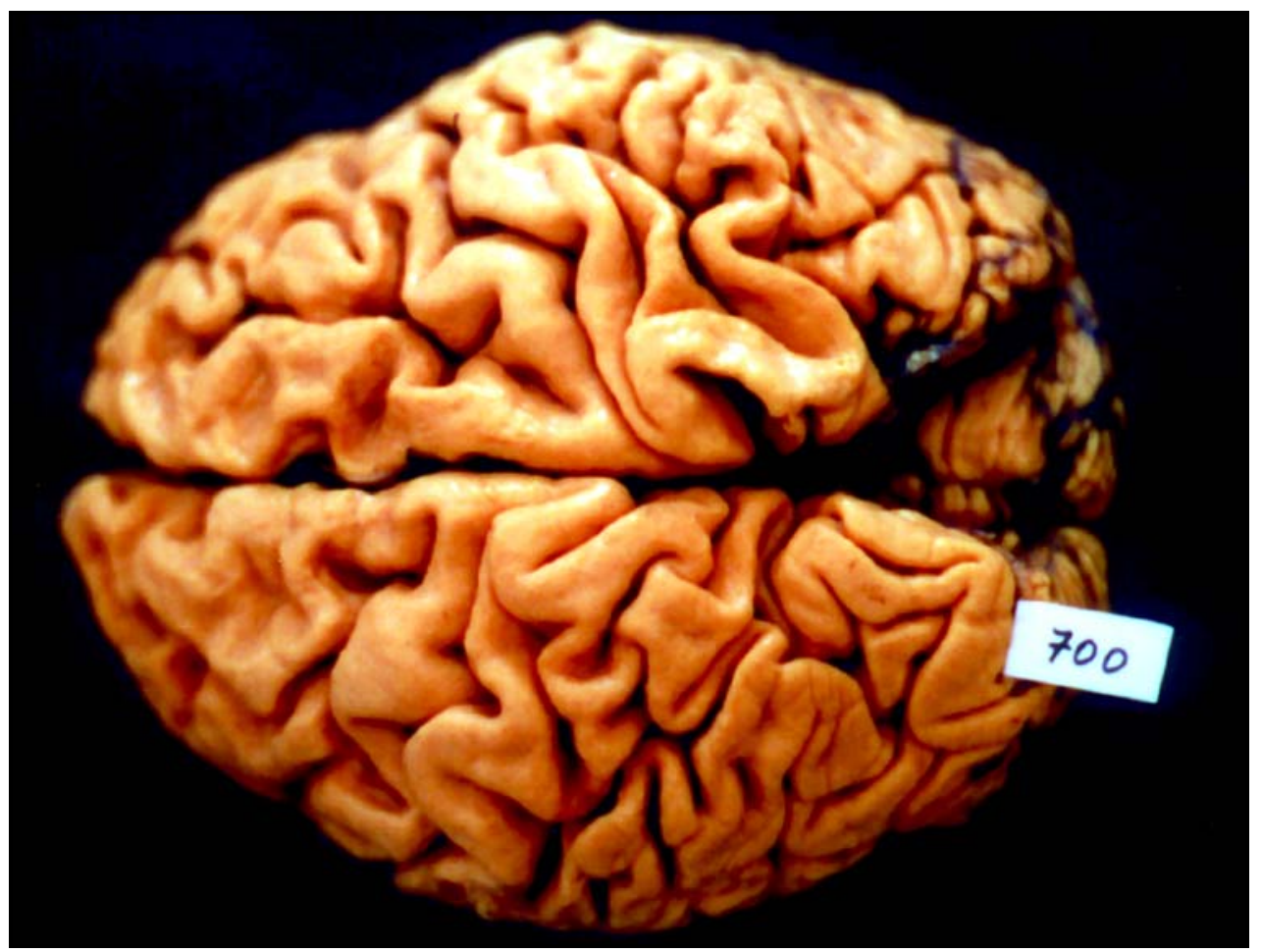

Fig 3. A macroscopical overview of the brain with frontoparietal cortical atrophy.

retaining the necessary motor power and coordination for these activities. She had presented a poorly organized paranoid delusional state, sometimes with visual hallucinations and also generalized tonic-clonic seizures. She took some phenobarbital until her death. Eventually, the patient lost the ability to stand and walk, being forced to lie inert on the chair or in bed. During the last year of her life, she remained bedridden with arms in flexion and legs extended (decorticate rigidity) and all personal needs were cared for by her familiy in bed. She died at the age 54, after a total clinical course of 14 years. She died in August
1999 due to respiratory infection problems. The clinical diagnosis was presenile dementia Alzheimer type.

She was approximately 150 centimeters tall and weighted $50 \mathrm{Kg}$. The brain was small, weighting 700 grammes before fixation. Macroscopic examination revealed cortical atrophy, especially severe on the frontal and moderate on the parietal and mild on the posterior third temporal lobes (Fig 3 and 4). The diagnostic confirmation was made by the histopathological findings of the autopsy that showed severe neuronal loss with status spongiosus (microvacuolation) and intensive gemistocytic gliosis in cor- 


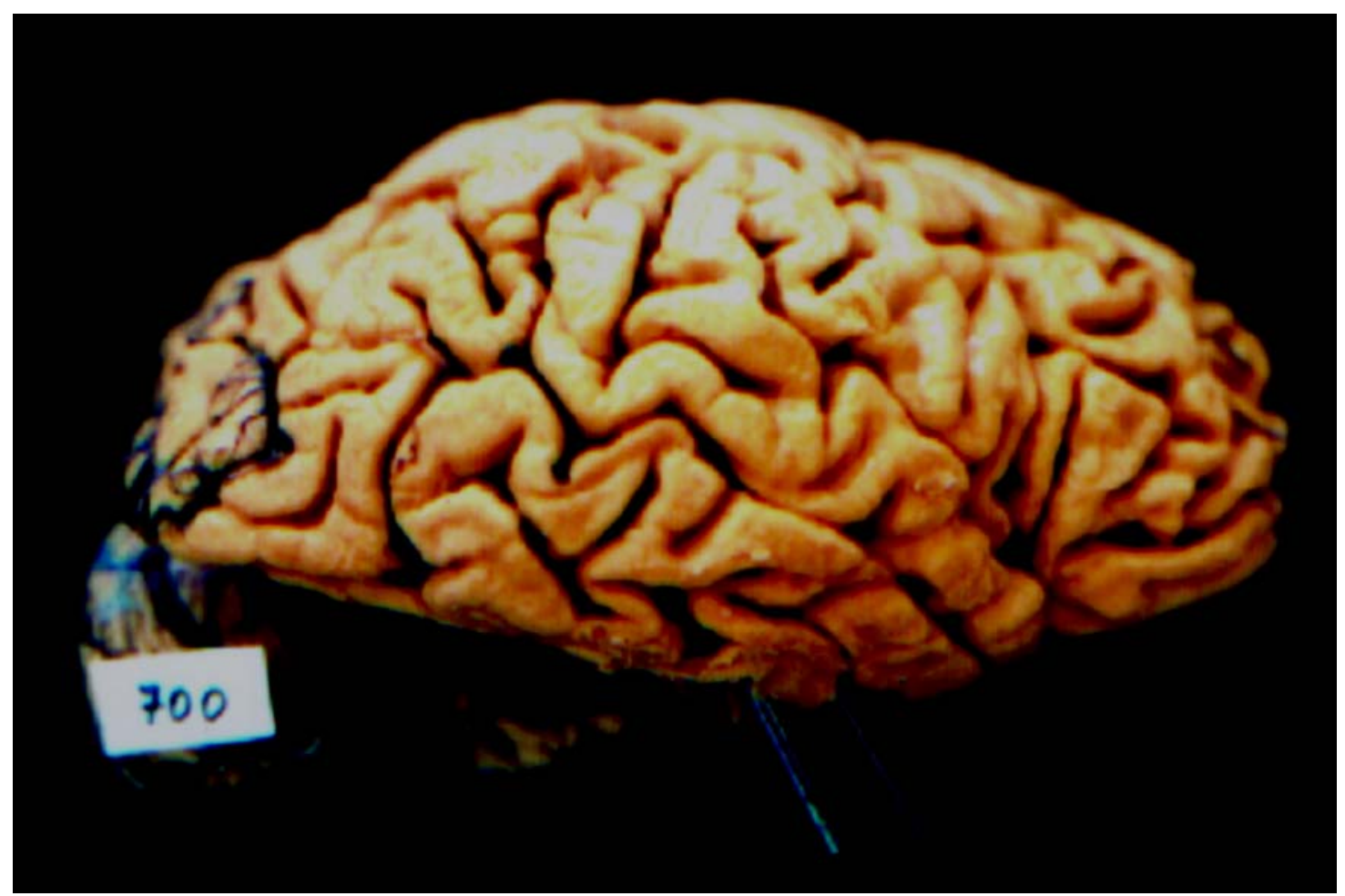

Fig 4. A macroscopical view of the right side of the brain showing a mild atrophy of the posterior temporal lobe.

tical structures (Fig 5). Hematoxylin-eosin and silver stains did not show neuronal swelling (balooned cell or Pick's cells), argyrophilic inclusion (Pick's bodies), neurofibrillary tangles, and senile plaques. Immunohistochemical staining for antibodies against ubiquitin, tau, $\beta$-amyloide, and prion proteins were tested negative. There was important absence of neurons. The residual neurons were sometimes normal, sometimes hypotrophic. No focal white matter or vascular lesions were observed.

\section{DISCUSSION}

This case presented a clinical picture suggestive of probable presenile AD in a patient who was not used to handling complex problems due to her poor schooling. Clinical patterns similar to those found in $A D$ patients occur also in non-AD patients, highlighting the difficulty of making a definitive diagnosis solely on clinical grounds ${ }^{18}$. Then, some data were not expected from the AD such as: a high protein content $(60 \mathrm{mg} / \mathrm{dl})$ was found in the CSF from a basal cistern sample, in opposition to the normal CSF usually seen in AD. The MRI showed slight bilateral frontal and parietal lobe atrophy without temporal lobe involvement. In cases of $A D$ is expected at least a mild parietal and especially temporal lobe atrophies on the MRI. Her brain 99mTcHMPAO SPECT showed moderate bilateral frontal and parietal lobe hypoperfusion, especially on the left side. In this last test we observed that the remaining grey matter hypoperfusion was ranged from 35 to $42 \mathrm{ml} / 100 \mathrm{~g} /$ tissue/ min (normal 65-85) ${ }^{19}$. However, it is also needed the involvement of both temporal lobes to be characterized as AD, according to what was described by Holman et al. ${ }^{20}$. Their criteria to the probability of $A D$ are the highest in patients with bilateral temporoparietal defects (82\%) and nearly as high (77\%) in patients with bilateral temporal and parietal defects plus other defects. We believed the probable $A D$ was the clinical diagnosis of this case because the symptoms had been characteristic, for instance: when she was about 41 years, she presented some features of episodic memory deficits - she went to a farm with her boss to spend a week, and when the photos arrived she denied that had gone there. The most of the episodic memory deficits presented by her had been of the autonoetic awareness type. The right frontal lobe, in particular, is thought to be relevant for episodic memory that conects the recall of personal past, and the related emocional associations, with plans for the future ${ }^{21}$. Also, when she started getting lost in well-known places, familiar to her, she asked for help to come back home. Some time later, she delayed to arrive at home as a result of getting lost in common streets. These two late facts suggest the involvement of parietal, frontal and temporal lobes. However, it was seen in her MRI and 


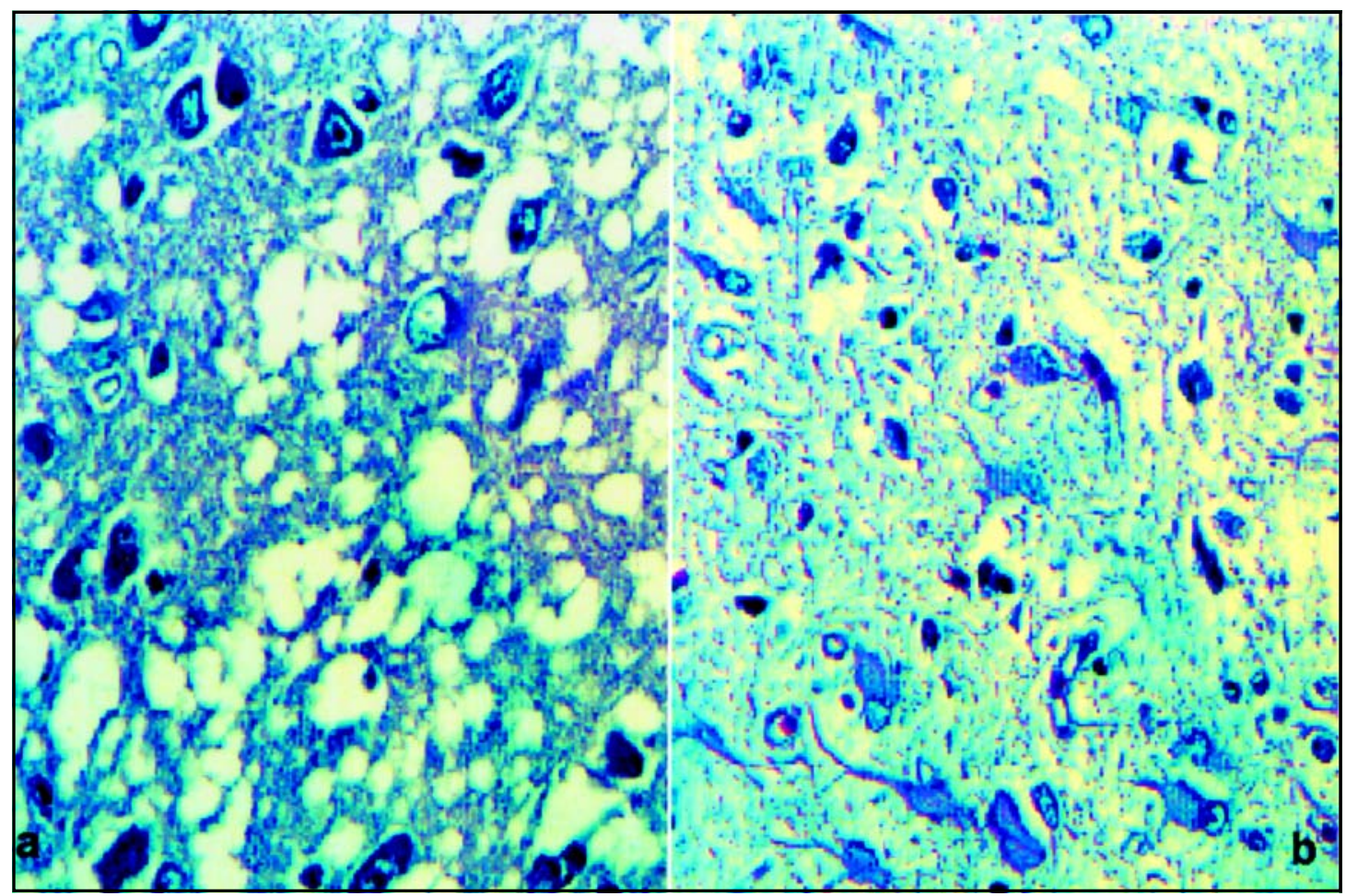

Fig 5 a,b. Severe neuronal loss with status spongiosus in cortical structures (HE $400 \mathrm{X}$ ). Severe neuronal loss with gemistocytic gliosis (HE 100X).

brain SPECT only impairment on the parietal and frontal lobes. Brain SPECT in AD is expected both in parietal and in temporal lobes to be involved. It is possible that some episodic memory deficits could have suffered influence of her poor schooling, but the fact that she got lost in places where she went shopping daily, we believed, could not be related to any poor schooling.

From the neuropathological point of view, there were a frontoparietal cortical atrophy related with spongiosis and a diffuse cortical gliosis (DCG). These changes were associated with neuronal loss without specific neuronal changes, and no remarkable myelin lesion. There was mild temporal lobe atrophy noted on its posterior region. The immunohistochemical reactions against tau, $\beta$-amyloid, ubiquitin and prion proteins in all the cerebral lobes were negative in tests. The clinical diagnosis of AD was not confirmed at the autopsy, because there were neither NTs nor SPs or immunohistochemical stainings against tau, $\beta$-amyloid and ubiquitin were tested negative. Reaction against prion-protein was performed by the spongiosis and intensive diffuse cortical gliosis, but it was also tested negative. The neuropathological findings showed compatible changes with cortical diffuse gliosis involving the gray matter of cerebral cortex, especially on the frontal and parietal lobes.
We observed a resemblance between our case and the $C_{2}$ type cases of Constantinidis et al. ${ }^{10}$. However, their $C_{2}$ type presents symptoms of frontal dementia type associated with circumscribed frontal cortical atrophy. The histological process spreads to the cingular, orbital, insular, and even temporal areas, but there is not extension to the parietal lobes. Besides, there is a varying involvement with the deep gray matter and strong gliosis is found in the white axis of atrophied convolutions. There were two different changes between the Constantinidis' et al. ${ }^{10}$ cases and this one. First, the macroscopic atrophy on the parietal lobes and the strong gliosis involving the cerebral cortex. This change presented some difference in the concept of Pick's lobar atrophy ${ }^{10}$. In the PD, the frontotemporal cortex is impaired for it always spares the posterior third of the superior temporal gyrus. In this case, the atrophy was severe on the frontal and mild on the posterior third on the temporal lobes. The parietal cortex is seldom involved, being moderately impaired in our case. The occipital cortex is always spared ${ }^{22}$. The association between the three lobes is possible, but only in very advanced disease. Acordding to Tissot et al. (apud Adams and Victor ${ }^{23}$ ) the frontal, temporal, and parietal lobes are all affected in 75 percent of patients on time disease terminates, even so they did not de- 
scribe isolated frontal and parietal atrophy. Second, there were not a very strong gliosis of the white matter and neostriatum, pallidum, thalamus and locus niger besides strongly dilated lateral ventricules as is described in the $C_{2}$ type cases $^{10}$. These are the two great differences found among our case and the described in the $\mathrm{C} 2$ type cases ${ }^{10}$. Another study by Neumann and Cohn" design a new entity as "progressive subcortical gliosis" (PSG) associated with a clinical picture of behavior and personality changes and presenile psychosis, but Neumann's cases are of frontal and temporal atrophy associated with PSG and they were different from ours.

In conclusion, nowadays, it seems impossible to distinguish clinically primary degenerative diseases without histological confirmation. The knowledge of the pathological features of this case, associated with the clinical picture of presenile dementia, show a rare case of inespecific cortical atrophy: 1) a severe frontal and moderate parietal and a mild posterior third temporal lobe atrophies; 2) the presence of strong gliosis in the gray matter of cerebral cortex without important involvement of white matter axis of atrophied convolutions; 3 ) the absence or a little gliosis in the subcortical structures, and the lateral dilated ventricules; 4 ) the absence of neuronal swellings and argyrophilic inclusions, besides senile plaques, neurofibrillary tangles, and prion protein were stained negative. Several other cases will be identified and further continuous and long-term clinicopathological studies are clearly needed.

\section{REFERENCES}

1. Neumann MA, Cohn R. Progressive subcortical gliosis: a rare form of presenile dementia. Brain 1967;90:405-418.

2. Razani J, Boone KB, Miller B, et al. Neuropsichological performance of right and left frontotemporal dementia compared to Alzheimer's disease. J Int Neuropsichol Soc 2001;7:468-480.
3. McKhann G, Drachman D, Folstein M, et al. Clinical diagnosis of Alzheimer's disease: report of the NINCDS-ADRDA work group under the auspices of Department of Health and Human Services Task Force on Alzheimer's disease. Neurology 1984;34:939-944.

4. Brito-Marques PR, Mello RV, Montenegro L. Amyotrophic lateral sclerosis with dementia. Arq Neuropsiquiatr 1999;57:277-283.

5. Brito-Marques PR, Mello RV, Montenegro L. Classic Pick's disease type with ubiquitin-positive and tau-negative inclusions. Arq Neuropsiquiatr 2000;59:128-133.

6. Nitrini R, Silva LST, Rosemberg S, et al. Prion disease resembling frontotemporal dementia and parkinsonism linked to cromosome 17. Arq Neuropsiquiatr 2001;59:161-164.

7. Kosaka K. Diffuse neurofibrillary tangles with calcification: a new presenile dementia. J Neurol Neurosurg Psychiat 1994;57:594-596.

8. Hamada K, Fukazawa T, Yanagihara T, et al. Dementia with ALS features and diffuse Pick body-like inclusions (atypical Pick's disease?). Clin Neuropathol 1995;14:1-6.

9. Schaumburg HH, Suzuki K. Non-specific familial presenile dementia. J Neurol Neurosurg Psychiat 1968;31:479-486.

10. Constantinidis J, Richard J, Tissot R. Pick's disease: histogical and clinical correlations. Eur Neurol 1974;11:208-217.

11. Rossor MN. Pick's disease: a clinical overview. Neurology 2001; 56(Suppl 4):S3-S5.

12. Brun A, Englund B, Gustafson L, et al. Clinical and neoropathological criteria for frontotemporal dementia. J Neurol Neurosurg Psychiat 1994;57:416-418.

13. Kertesz A, Davidson W, Munoz DG. Clinical and pathological overlap between frontotemporal dementia, primary progressive aphasia and corticobasal degeneration: the Pick complex. Dement Geriatr Cogn Disord 1999;10 (Suppl.):46-49.

14. Neary D, Snowden JS, Northen B, et al. Dementia of forntal lobe type. J Neurol Neurosurg Psychiat 1988;58:353-361.

15. Folstein MF, Folstein SE, McHugh PR. Mini-mental state: a pratical method for grading the cognitive state of patients for the clinician. J Psychiat Res 1975; 12:189-198.

16. Hughes CP, Berg L, Danziger WL, et al. A New clinical scale for the staining of dementia. Br J Psychiatry 1982;140:566-572.

17. European Concerted Action on Pick's Disease (ECAPD) Consortium: Provisional clinical and neurophatological criteria for the diagnosis of Pick's disease Eur Neurol 1998;5:519-520.

18. Neary D, Snowden JS, Bowen DM, et al. Neuropsychological syndromes in presenile dementia due to cerebral atrophy. J Neurol Neurosurg Psychiatry 1986; 49:163-174.

19. Ingvar DH, Cronqvist $\mathrm{S}$, Ekbert $\mathrm{R}$, et al. Normal values of regional cerebral blood flow in man, including flow and weight estimates of gray and matter. Acta Neurol Scand (Suppl.) 1965;14:72-78.

20. Holman BL, Johnson KA, Gerada B, et al. The scintigraphic appearence of Alzheimer's disease: a prospective study using technetium-99mHMPAO SPECT. J Nucl Med 1992;33:181-185.

21. Wheeler MA, Stuss DT, Tulving E. Toward a theory of episodic memory: the frontal lobes and autonoetic consciousness. Psychol Bull 1997; 121:331-354.

22. Escourolle R, Poirier J. Manual of basic neuropathology. 2.Ed. Philadelphia: Saunders. 1978:242.

23. Adams RD, Victor M. Principles of neurology 5.Ed. New York: McGraw-Hill, 1993:1394. 